\title{
Persepsi Pemilih Pemula tentang Hak Memilih dalam Mengikuti Pemilu di Nagari Tanjung Gadang Kabupaten Sijunjung
}

\author{
Ridhatul Setyawan, Alia Azmi \\ Program Studi Pendidikan Pancasila dan Kewarganegaraan \\ Universitas Negeri Padang \\ E-mail: ridhatuls@gmail.com
}

\section{ABSTRAK}

Penelitian ini dilatarbelakangi oleh munculnya anggapan tentang krisis kepercayaan kepada pemimpin karena Indonesia belum mampu untuk maju ke arah yang lebih baik lagi. Hal ini tentunya berdampak kepada generasi muda yang baru pertama kali ingin memilih dalam Pemilu. Tujuan penelitian ini adalah untuk menggambarkan persepsi pemilih pemula tentang hak memilih dalam mengikuti Pemilu di Kenagarian Tanjung Gadang, Kecamatan Tanjung Gadang, Kabupaten Sijunjung. Sumatera Barat. Metode yang digunakan adalah deskriptif kualitatif yang bertujuan untuk melakukan penelusuran dan memperoleh gambaran terhadap hal yang diteliti. Hasil penelitian menunjukkan bahwa persepsi pemilih pemula tentang hak memilih dalam mengikuti Pemilu ditinjau dari sisi pengetahuan yang dimiliki pemilih masih dikategorikan rendah. Hal ini ditunjukkan dari pendidikan yang didapatkan dalam keluarga tentang hak memilih cenderung masih berupa paksaan, ditambah dengan pemahaman yang kurang dari pemilih pemula. Hal ini meliputi: tidak mengetahui syarat Pemilu, undang-undang yang mengatur serta proses dan sistem Pemilu yang berlaku. Pemilih pemula ini memiliki ketertarikan memilih karena pengaruh media massa namun mereka tidak paham dengan teori, konsep serta tujuan Pemilu sebagai upaya pemerintah untuk memwadahi aspirasi warga negara. Potensi yang dimiliki oleh pemilih pemula adalah semangat yang cukup tinggi, oleh karena itu pemerintah maupun pihak keluarga dapat lebih memberikan pemahaman kepada pemilih pemula untuk mengunakan hak memilih mereka. Sehingga dapat meningkatkan kesadaran untuk memilih dalam Pemilu.

Kata Kunci: pemilih pemula, pemilu, Sijunjung, Sumatera Barat

\section{ABSTRACT}

This research is motivated by the emergence of assumptions about the crisis on trust in leadership [ because Indonesia has not been able to move forward to a better direction. This certainly has an impact on young people who are the first voters. The purpose of this study is to describe the perceptions of first voters on right to vote in the General Election in Kenagarian Tanjung Gadang, Tanjung Gadang District, Sijunjung Regency, West Sumatra. The method used in this research is descriptive qualitative which aims to search and obtain a complete overview. The results showed that the perception of first voters in the election in terms of the knowledge possessed by voters was still categorized as low. This is shown from the family 
education on right to vote which tends to be coercion and lack of understanding from the first voter. This includes: don't know the election requirements, the laws that used, the election processes and systems that apply. These first voters have an interest in voting because of the influence of media but they do not understand the theories, concepts and objectives of the General Election as an attempt by the government to accommodate the aspirations of citizens. The potential possessed by the first voter is they have high enough enthusiasm, therefore the government and the family can better provide understanding to the first voter to exercise their voting rights. So as to increase awareness to vote in elections.

Keywords : perception, first voters, elections, Sijunjung, West Sumatra

(c) () (2) This work is licensed under the Creative Commons Attribution-ShareAlike 4.0 International License. $\odot 2019$ EY SA by author. 


\section{PENDAHULUAN}

Di setiap penyelenggaraan Pemilu tidak terlepas dari adanya pemilih pemula. Mereka adalah pemuda yang baru pertama kali mengikuti dan menyalurkan hak pilihnya. Menurut undang-undang nomor 10 tahun 2008, pemilih pemula adalah mereka yang telah berumur 17 tahun atau baru pertama kali melakukan pemilihan umum. Pada umumnya mereka adalah pelajar SMA. Pada masa sekarang pemilih pemula yang lebih dikenal sebagai generasi milenial sudah bisa menilai serta memiliki persepsi politiknya sendiri. Hal ini disebabkan karena kemajuan teknologi dan informasi yang pesat yang dapat mendukung pengetahuan dan kreativitas para remaja tersebut. Kemajuan ini juga telah menjadikan para remaja lebih kritis dalam menghadapi suatu isu perubahan yang terjadi di masyarakat, terutama isu politik. Berdasarkan hal tersebut, sudah sewajarnya para pemilih pemula memiliki persepsi politiknya sendiri tanpa dipengaruhi oleh orang lain.

Pemilih pemula merupakan salah satu kelompok pemilih yang memiliki efek dan dampak yang sangat signifikan untuk mempengaruhi besarnya perolehan suara dalam pemilu. Berdasarkan data yang dirilis oleh BPS (2018), pada pemilu 2009 pemilih pemula mencapai 36 juta dan pada pemilu serentak tahun 2019 pemilih pemula berjumlah lebih dari 36 juta

Menurut Rafni \& Suryanef (2019) dikatakan bahwa pemilih pemula digambarkan melalui perilaku sebagai berikut: (1) Pemilih yang masih labil; (2) Pemilih yang memiliki pengetahuan politik yang relatif rendah; (3) Pemilih yang cenderung didominasi oleh kelompok (Peergroup); (4) pemillih yang melakukan pilihan karena aspek popularitas; (5) pemilih yang datang ke tempat pemungutan suara hanya untuk mendaftarkan dan menggugurkan haknya.

Menurut

penelitian Soeprapto (2015) menyebutkan bahwa pemilu sering dipersepsikan sebagai sebuah instrumen politik untuk menguji dan menentukan apakah system politik bersifat demokratis atau tidak. Maka swing voter pemilih pemula memiliki posisi signifikan sebagai pendorong terjadinya politik yang bersifat demokratis tersebut. Sedangkan menurut penelitian Hasanah (2014) menyatakan bahwa pemberitaan yang dilakukan oleh media massa dapat mengkonstruksi pemilih pemula untuk menentukan sikap dan minat mereka untuk memilih dalam pemilu, terutama mengenai isu- isu 
politik yang mengarah kepada persaingan.

Dengan demikian dapat diasumsikan bahwa pemilih pemula dalam mengikuti pemilu ini hanya sebagai pemilih yang labil, serta pengetahuan yang kurang dan hanya sebagai instrumen politik saja. Berdasarkan hal tersebut, diperlukan kajian lebih lanjut bagaimana persepsi pemilih pemula tentang hak memilih dalam mengikuti pemilu.

\section{METODE PENELITIAN}

Artikel ini merupakan bagian dari penelitian penulis yang berjudul Persepsi Pemilih Pemula tentang Hak Memilih dalam Mengikuti Pemilu di Kenagarian Tanjung Gadang, Kecamatan Tanjung Gadang, Kabupaten Sijunjung. Penelitian ini menggunakan metode kualitatif dan informan ditentukan secara purposive sampling. Informan penelitian ini adalah para pemilih pemula di Kenagarian Tanjung Gadang yang berusia 17-21 tahun serta belum memiliki pengalaman memilih dalam pemilu sebelumnya. Pengumpulan data dilakukan melalui wawancara, observasi dan teknik dokumentasi. Selain itu teknik pengujian keabsahan data dilakukan melalui teknik pengumpulan data, reduksi data, display dan verifikasi data

\section{HASIL DAN PEMBAHASAN}

Persepsi pemilih pemula ini sangat diperlukan karena dengan adanya persepsi ini para pemilih pemula dapat memproses informasi yang mereka dapatkan serta membuat penilaian terhadapnya. Untuk selanjutnya mereka dapat memutuskan apa yang hendak dilakukan dikemudian hari jika harus mengikuti Pemilu selanjutnya.

Temuan penelitian di Kenagarian Tanjung Gadang, Kecamatan Tanjung Gadang, Kabupaten Sijunjung menunjukkan bahwa pemilih pemula yang mengikuti pemilu serentak tahun 2019 belum memiliki rasa rasionalitas yang tinggi. Padahal untuk menumbuhkan sikap rasionalitas diperlukan dukungan dari berbagai pihak termasuk keluarga bukan hanya dari pemerintah.

Menurut Efriza (2012) terdapat dua cara sifat perilaku pemilih dalam memilih yakni; pemilih rasional (rational votters) dan pemilih tradisional (traditional votters). Kelompok pertama adalah pemilih yang menggunakan hak pilihnya tanpa dipengaruhi oleh orang lain. Sementara itu kelompok kedua adalah pemilih yang menggunakan hak pilih yang bukan datang dari kehendak sendiri melainkan dari orang lain, 
seperti dorongan dari orang tua ataupun tokoh masyarakat maupun pemerintah.

Berdasarkan penelitian yang ditemukan di Kenagarian Tanjung Gadang, Kecamatan Tanjung Gadang, Kabupaten Sijunjung dapat dikatakan bahwa para pemilih pemula di sana belum rasional. Hal tersebut diakibatkan karena pemahaman yang mereka dapatkan lebih ke arah pemaksaan seperti pemaksaan untuk memilih salah satu pasangan calon (paslon) yang diyakini orang tuanya baik sehingga si anak juga harus memilih paslon tersebut. Dalam Pemilu ini juga ditemukan bahwa para pemilih pemula ini tidak terlalu mengetahui syarat seseorang bisa mengikuti pemilu, asas-asas yang ada dalam pemilu bahkan juga tidak bisa terlalu membedakan surat suara yang ada dalam pemilu serentak 2019. Pembedaan surat suara memang agak sulit dilakukan oleh kebanyakan orang karena dalam pemilu serentak tahun 2019 terdapat 5 surat suara sehingga bisa membuat kebanyakan orang agak sulit membedakannya. Hal ini menunjukkan bahwa pemilih pemula di Kenagarian Tanjung Gadang, Kabupaten sijunjung masih menganut system tradisional votters. .
Lebih lanjut penelitian menemukan bahwa pemilih pemula sangat dipengaruhi oleh media massa untuk menentukan hak memilih mereka dalam pemilu. Berdasarkan dari yang disampaikan oleh informan, mereka lebih mempercayai informasi dari media massa karena informasinya dapat diketahui secara cepat dan tidak banyak membuang waktu. Namun mereka juga menyadari bahwa harus memilih informasi yang baik dengan memilah dulu informasi yang didapatkan tersebut. Selain itu, motivasi yang mereka dapatkan untuk ikut serta dalam memilih lebih banyak disebabkan karena paksaan dari orang tua. Hal ini mencerminkan pemikiran yang masih labil dari pemilih pemula tersebut.

Di Indonesia para pemilih terutama pemilih pemula masih banyak yang menjadi tradisional votters karena kebiasaan anak untuk meniru orang tua. Padahal seharusnya pemilih pemula tersebut memiliki rasionalitas dalam memilih yang berasal dari kehendak sendiri berdasarkan pengetahuan yang cukup, motivasi yang jelas serta informasi untuk memilih. Keseluruhan hal tersebut berdasarkan kepada pemikiran yang logis serta demi kepentingan umum dan bukan perorang saja. 


\section{SIMPULAN}

Rasional votters sangat diperlukan untuk menghasilkan generasi terutama pemilih pemula yang kritis serta berani menyalurkan hak pilihnya dengan kehendaknya sendiri tanpa harus ada paksaan dari siapapun. Hal ini dapat menjadi dasar menuju pemilih yang cerdas.

Adapun saran yang dapat disampaikan sesuai dengan hasil penelitian ini adalah: pertama, seluruh pihak tidak terkecuali orang tua, masyarakat serta pemerintah harus lebih giat memberikan pendidikan kepada anak terutama yang telah memiliki hak pilih dalam pemilu dengan cara menggunakan pemahaman yang lebih mudah mereka pahami. Kedua, pemilih pemula pada zaman sekarang juga harus lebih mampu untuk mandiri dalam mencari informasi tentang isu politk yang terjadi saat ini

\section{DAFTAR PUSTAKA}

Efriza. 2012. Political Explore : Sebuah Kajian Ilmu Politik. Bandung: Alfabeta

Hasanah, Ratih \& Aprianti, Agus. Pemanfaatan Media Massa Dalam Komunikasi Politik Pemilihan Calon Presiden (Konstruksi Realitas Pemilih Pemula dalam Pemilihan Presiden 2014). Program Studi Ilmu Komunikasi,
Telkom University. 2016. https://ratihhasanah.staff.te lkomuniversity.ac.id/files/2 016/12/PemanfaatanMediaMassa-Dalam-KomunikasiPolitik-Pemilihan-CalonPresiden.pdf diakses pada 30 Agustus 2019

Rafni, A., \& Suryanef, S. (2019). Voter Education for First Time Voters through Rumah Pintar Pemilu. Journal of Moral and Civic Education, $3(1), 1-8$.

Soeprapto, A., Susilasti, D. N., \& Suparno, B. A. (2015). Komunikasi Dalam Proses Pendidikan Politik Pemilih Pemula Dalam Pemilihan Umum 2014 di DIY. Jurnal Ilmu Komunikasi, 12(1).

Suryanef, S., \& Rafni, A. (2015). Pendidikan Pemilih (Voter's Education) Bagi Pemilih Pemula Serta Urgensinya Dalam Pembangunan Demokrasi. Prosiding SNaPP: Sosial, Ekonomi dan Humaniora, 5(1), 571-576. 